\title{
Membaca Jejak Proses Kreatif Penyair Nusa Tenggara Timur, John Dami Mukese
}

\author{
Reading East Nusa Tenggara Poet Creative Process Tracks, John Dami Mukese
}

\author{
Yohanes Sehandi ${ }^{1}$ dan Alexander Bala ${ }^{2, *}$ \\ ${ }^{1,2}$ Program Studi Pendidikan Bahasa dan Sastra Indonesia, \\ Fakultas Keguruan dan Ilmu Pendidikan, Universitas Flores \\ ${ }^{1}$ Email: yohanessehandi@gmail.com \\ 2,*Correspondence email: naradiring@gmail.com
}

\begin{abstract}
This article explores the poet John Dami Mukese's creative process in creating his poetry. John Dami Mukese is an Indonesian poet born in Flores, a Catholic priest who wrote about 250 poems. This study uses an expressive approach, which is an approach that emphasizes the study of literary authors. The method used is the codification method, which is the observation method by tracing the colophon in each poem. Colophons are notes at the end of a text that informs the author's place, time, and name. The analysis used is a qualitative analysis by describing the poet's creative process in creating his poetic works. The study results show that the creative process of poet John Dami Mukese began at the age of 27 years, namely, in 1977. The first three years (1977-1979) were the beginning of his creative process by finding the correct pronunciation by his personality, educational background, and profession. Over the next four years (1980-1984) was the peak period of creativity and productivity of poet John Dami Mukese in creating his poetry. From 1985 until the end of 2017, it was an anticlimax in the creative process. The poems of John Dami Mukese with religious themes based on social problems show a very deep sensitivity to the social reality that is taking place in Flores society.

Keywords: creative process, expressive approach, codification method, colophon technique
\end{abstract}

\begin{abstract}
Abstrak: Artikel ini bertujuan untuk menelusuri proses kreatif penyair John Dami Mukese dalam menciptakan karya-karya puisinya. John Dami Mukese adalah penyair Indonesia kelahiran Flores, berlatar belakang sebagai pastor Katolik yang telah menulis sekitar 250 puisi. Kajian ini menggunakan pendekatan ekspresif, yakni pendekatan yang menitikberatkan kajian pada pengarang sastra. Metode yang digunakan adalah metode kodifikasi, yakni metode pernaskahan dengan menelusuri kolofon pada setiap puisi. Kolofon adalah catatan pada bagian akhir naskah yang menginformasikan tentang tempat, waktu, dan nama penulis. Analisis yang digunakan adalah analisis kualitatif dengan mendeskripsikan tahapan proses kreatif penyair dalam menciptakan karya-karya puisinya. Hasil kajian menunjukkan bahwa proses kreatif penyair John Dami Mukese dimulai sejak berumur 27 tahun, yakni tahun 1977. Selama tiga tahun pertama (1977-1979) merupakan masa awal proses kreatifnya dengan mencari bentuk pengucapan yang tepat sesuai dengan kepribadian dan latar belakang pendidikan dan profesinya. Selama empat tahun berikutnya (1980-1984) adalah masa puncak kreativitas dan produktivitas penyair John Dami Mukese dalam menciptakan karya-karya puisinya. Sejak tahun 1985 sampai dengan akhir hayatnya 2017, adalah masa antiklimaks dalam proses kreatifnya. Puisi-puisi John Dami Mukese bertema religius yang berbasis pada masalah sosial, menunjukkan sensitivitas sangat mendalam terhadap realitas sosial yang tengah berlangsung dalam masyarakat Flores.
\end{abstract}

Kata kunci: proses kreatif, pendekatan ekspresif, metode kodifikasi, teknik kolofon

To cite this article:

Sehandi, Y., \& Bala, A. (2021). Membaca Jejak Proses Kreatif Penyair NTT, John Dami Mukese. Diglosia: Jurnal Kajian Bahasa, Sastra, dan Pengajarannya, 4(1), 23-36. https://doi.org/10.30872/diglosia.v4i1.88 


\section{A. PENDAHULUAN}

Setiap karya sastra yang dihasilkan memiliki kandungan nilai yang tinggi. Keberadaannya tidak sekadar sebagai suatu teks kosong, namun lebih dari itu merupakan puncak gagasan penyairnya atas gejala sosial kehidupan masyarakat. Bahkan, karya sastra itu sendiri merupakan jelmaan hasil pemikiran tentang sesuatu yang akan datang. Menempatkan karya sastra seperti ini berarti meletakkan suatu karya sastra sebagai bagian dari khazanah budaya masyarakat sekaligus menjadi obyek yang selalu menarik untuk dikaji. Di dalamnya terdapat pengalamanpengalaman humanitas atau pengalaman-pengalaman perjumpaan manusia yang satu dengan manusia yang lain dalam kehidupan sosial. Pengalaman tentang suka, duka, sakit, penyakit, dan pengalaman lain yang menyertai kehidupan manusia itu sendiri.

Sebagai suatu karya seni manusia yang menggunakan bahasa sebagai mediumnya, karya sastra memiliki pelbagai macam pendekatan untuk mengkajinya. Mengkaji karya sastra, tidaklah cukup hanya berpedoman pada pengarangnya atau karya itu sendiri karena karya sastra masih memiliki unsur lain, yaitu dunia karya sastra, pembaca karya-karya sastra dan latar belakang pengarangnya (Anggaira \& Emawati, 2018, hal. 76). Pada aspek pengalaman kemanusiaan inilah karya sastra, seperti puisi menjadi selalu merangsang untuk dikaji demi menemukan nilai yang menjadi jalan keluar bagi masyarakat sastra saat menghadapi persoalan hidup.

Salah satu pendekatan sastra Abrams (1971, hal. 21-26) adalah pendekatan ekspresif. Pendekatan ekspresif adalah pendekatan yang menitikberatkan kajian pada penyair sastra. Karya sastra dilihat sebagai proses kreatif pengarang sebagai pencipta. Pengarang adalah tokoh yang tidak terpisahkan dari karya sastra. Tanpa pengarang tidak akan lahir karya sastra. Karya sastra adalah anak kandung pengarangnya. Menurut Damono (2018, hal. 1-2), dalam sejarah panjang perjalanan sastra dunia, pendekatan yang menitikberatkan kajian pada pengarang banyak dilakukan pada masa romantik. Pada masa tersebut, pengarang mendapat sorotan yang khas, sebagai pencipta yang kreatif, dan jiwa pencipta mendapat minat utama dalam penilaian dan pembahasan karya sastra. Secara konseptual dan metodologis pendekatan ekspresif menempatkan karya sastra sebagai: (1) wujud ekspresi pengarang, (2) produk imajinasi pengarang yang bekerja dengan persepsi-persepsi, pikiran-pikiran dan perasaan-perasaannya, (3) produk pandangan dunia pengarang (Anggaira \& Emawati, 2018, hal. 86). Dengan demikian, pendekatan kajian sastra ekspresif dalam penelitian ini meletakkan karya sastra pengarang sebagai rangkaian emosi atau perasaan yang sekaligus membangkitkan emosi atau perasaan para pembaca.

Pengarang dan karya yang dikaji adalah John Dami Mukese (JDM), yang dikenal sebagai penyair NTT. Dia seorang penyair religio-sosial yang berlatar belakang sebagai pastor Katolik dari Kongregasi Serikat Sabda Allah (SVD). Dia adalah seorang penyair kelahiran Flores, Provinsi Nusa Tenggara Timur (NTT). Di NTT penyair JDM dikenal luas sebagai penyair NTT atau sastrawan NTT, yakni sastrawan Indonesia kelahiran NTT. Sastrawan NTT yang lain adalah Gerson Poyk, Dami N. Toda, Umbu Landu Paranggi, Julius Sijaranamual, Maria Matildis Banda, Usman D. Ganggang, Mezra E. Pellondou, Mario F. Lawi, Felix K. Nesi, dan lainlain (Sehandi, 2012, hal. 40-70). JDM telah menerbitkan lima judul buku antologi puisi pribadi. Banyak pula puisinya yang masuk dalam buku antologi bersama penyair Indonesia lain, antara lain dalam buku Tonggal 4: Antologi Puisi Indonesia 
Modern (Editor Linus Suryadi AG, Jakarta, Gramedia, 1987), Senja di Kota Kupang: Antologi Puisi Sastrawan NTT (Kupang, Kantor Bahasa NTT, 2013), dan Ratapan Laut Sawu: Antologi Puisi Penyair NTT (Editor Yoseph Yapi Taum, Yogyakarta, Universitas Sanata Dharma, 2014).

Artikel ini mengkaji jejak proses kreatif penyair JDM dalam menghasilkan karya-karya puisinya. Proses kreatif penyair ditelusuri dari segi waktu dan tempat kelahiran puisi-puisinya dengan mencatat kolofon setiap puisi. Kolofon adalah catatan pada bagian awal dan akhir naskah karya sastra (puisi) yang menginformasikan tentang nama orang yang ditujukan penyair sebagai persembahan, nama penyair, nama tempat dan waktu karya sastra itu diciptakan. Kolofon adalah sumber penelusuran proses kreatif seorang pengarang, dalam hal ini penyair JDM. Tujuan penelitian ini yakni mendeskripsikan jejak kreatif pengarang JDM. berdasarkan tema/amanat secara keseluruhan sesuai dengan kondisi sosial masyarakat yang menjadi latar belakang penciptaan karya-karya JDM tersebut.

\section{B. METODE}

Metode penelitian yang digunakan adalah metode kodikologi, yakni metode pernaskahan yang berpusat pada fisik naskah. Menurut Mulyadi (melalui Mu'jizah, 2018, hal. 33), kodikologi bertujuan untuk mengungkap sejarah pernaskahan dengan melakukan penelusuran terhadap biografi dan jejak langkah pengarang, penyalin, iluminasi, waktu, dan tempat penciptaan karya sastra. Kodikologi menelusuri berbagai data kolofon yang terdapat pada bagian akhir setiap naskah. Obyek kajian ini, yakni 2 puisi penyair JDM. Pertama, puisi pertama JDM Sebuah Percakapan di Sebuah Kota Kecil, Timor yang dimuat pada majalah Dian (terbitan Ende, Flores), edisi Nomor 6, Tahun VI, 10 Januari 1979, halaman 6. Kedua, puisi "Doa-Doa Semesta" yang terdiri atas 20 bait dan 296 baris dimuat dalam majalah sastra Horison pada edisi Nomor 2, Tahun 1983, halaman 86-89.

Penelusuran jejak penciptaan puisi-puisi JDM dilakukan dengan teknik inventarisasi dan identifikasi terhadap berbagai data kolofon yang tercantum pada bagian akhir setiap puisi. Inventarisasi dilakukan untuk mengetahui jenis-jenis karya sastra yang diciptakan penyair. Selanjutnya dilakukan identifikasi atas karya-karya tersebut berdasarkan data kolofon pada setiap puisi untuk mengetahui urutan waktu secara kronologis kelahiran setiap puisi yang diciptakannya. Terakhir dilakukan interpretasi atas tema/amanat secara keseluruhan puisi sesuai dengan kondisi sosial masyarakat yang menjadi latar belakang penciptaan karya tersebut. Seluruh hasil kajian disusun dalam bentuk deskriptif kualitatif yang berisi tahapan proses kreatif dan jejak langkah (biografi) penyair JDM sampai ia meninggal pada 2017.

\section{PEMBAHASAN}

Untuk dapat menelusuri dan mengungkapkan proses kreatif penyair John Dami Mukese, terlebih dahulu diungkapkan riwayat hidup atau jejak langkah penyair ini. JDM lahir pada 24 Maret 1950 di Menggol, Manggarai Timur, Provinsi NTT. Meninggal dunia pada Kamis, 26 Oktober 2017 di RSUD Ende, dalam usia 67 tahun. Menamatkan SD di Pembe (1964), SMTP dan SMTA di Seminari Menengah Pius XII Kisol (1971), Sekolah Tinggi Filsafat Katolik (STFK) Ledalero, Maumere (1980). Ditahbiskan menjadi imam Katolik dalam Kongregasi Serikat Sabda Allah 
(SVD) pada 19 Juli 1981. Meraih gelar Master of Management (MM) dalam bidang manajemen pembangunan masyarakat desa pada University of The Philipines Los Banos (1983-1987). Meraih gelar Ph.D. (Doktor) dalam bidang Community Development diperoleh pada University of The Philipines Los Banos (2005-2009).

Pernah menjadi pemimpin redaksi majalah Vox terbitan STFK Ledalero, Maumere. Menjadi pemimpin redaksi majalah dua mingguan Dian, surat kabar mingguan Dian, dan harian umum Flores Pos, ketiganya terbit di Ende, Flores. Mengasuh sejumlah mata kuliah di Sekolah Tinggi Pastoral Atma Reksa (Stipar) Ende dan Sekolah Tinggi Pembangunan Masyarakat (STPM) Santa Ursula Ende. Menjadi pembina dalam Komunitas Sastra Puisi Jelata (KPJ) Program Studi Pendidikan Bahasa dan Sastra Indonesia (PBSI) Universitas Flores (Uniflor) dan Komunitas SARE (Sastra Rakyat Ende) di Ende. Karya-karya puisinya yang sudah diterbitkan dalam bentuk buku adalah (1) Doa-Doa Semesta (Ende, Nusa Indah, 1983), (2) Puisi-Puisi Jelata (Ende, Nusa Indah, 1991), (3) Doa-Doa Rumah Kita (Ende, Nusa Indah, 1996), (4) Puisi Anggur (Ende, Nusa Indah, 2004), dan (5) Kupanggil Namamu Madonna (Malang, Dioma, 2004).

Nama penyair JDM dikenal di panggung sastra nasional Indonesia pada waktu puisi panjangnya berjudul "Doa-Doa Semesta" dimuat dalam majalah sastra Horison pada edisi Nomor 2, Tahun 1983, halaman 86-89. Puisi ini ditulisnya selama dua bulan, Juli-Agustus 1982 di Biara Santu Yosef, Ende. Dialah orang NTT pertama yang karyanya bisa tembus majalah sastra Horison, meskipun tinggal dan berkarya di daerah (Flores). Memang sebelumnya sudah ada orang NTT yang karyanya tembus majalah Horison, tetapi tinggal dan berkarya di Jakarta, seperti Gerson Poyk, Julius Sijaranamual, Dami N. Toda, dan Ignas Kleden.

Pada waktu itu majalah sastra Horison dianggap semacam "sungai Yordan" atau tempat pembaptisan seorang pengarang menjadi sastrawan Indonesia. Tim redaksi Horison pada waktu itu adalah tokoh-tokoh kaliber sastra Indonesia, yakni H.B. Jassin, Taufiq Ismail, Sapardi Djoko Damono, dan Sutardji Calzoum Bachri. Menurut peneliti, puisi panjang "Doa-Doa Semesta" yang terdiri atas 20 bait dan 296 baris ini merupakan puisi unggulan (masterpiece) JDM selama kariernya sebagai penyair. Puisi ini seakan merangkum semua tema dan gaya pengucapan puisi yang dihasilkannya. Mungkin itu pula sebabnya, buku kumpulan puisi pertamanya diberi judul Doa-Doa Semesta (1983).

Sejak tahun 1983 itulah nama penyair JDM diperbincangkan oleh sejumlah pengamat dan kritikus sastra Indonesia modern di tingkat nasional. Pada tahun 1987, sebanyak sepuluh puisi Dami Mukese masuk dalam buku Tonggak 4: Antologi Puisi Indonesia Modern dengan Editor Linus Suryadi AG (Gramedia, Jakarta, 1987, halaman 36-44). Di samping masuk dalam Tonggak 4: Antologi Puisi Indonesia Modern, puisi-puisi JDM yang lain juga masuk dalam buku antologi Senja di Kota Kupang: Antologi Puisi Sastrawan NTT (Kantor Bahasa NTT, 2013, halaman 24-35) termuat empat judul puisi Dami Mukese. Puisinya yang lain masuk dalam buku antologi Ratapan Laut Sawu: Antologi Puisi Penyair NTT (Universitas Sanata Dharma, Yogyakarta, 2014, halaman 35-51, Editor Yoseph Yapi Taum) termuat sembilan puisi JDM. Dalam buku Yohanes Sehandi Mengenal Sastra dan Sastrawan NTT (Universitas Sanata Dharma, Yogyakarta, 2012, halaman 50-51) dibahas khusus riwayat hidup dan karya penyair JDM bersama puluhan sastrawan NTT yang lain. Yang terbaru tahun 2017 sebelum beliau meninggal dunia, penyair JDM masuk dalam buku Apa \& Siapa Penyair Indonesia (Editor Maman S. Mahayana, Yayasan 
Hari Puisi Indonesia, Jakarta, 2017, halaman 362-363). Buku tebal ini memuat riwayat hidup dan riwayat karya para penyair Indonesia, termasuk JDM.

Sampai dengan tahun 2017 JDM adalah penyair NTT yang paling banyak menerbitkan buku kumpulan puisi. Jumlah puisi penyair ini selama kariernya sebagai penyair (1977-2017) yang termuat dalam lima judul buku kumpulan puisi pribadinya dan ditambah dengan puisi-puisinya yang dimuat dalam buku antologi puisi bersama penyair Indonesia lain, ditambah pula dengan puisi-puisi lain tersebar di berbagai media cetak, kalau dijumlahkan sekitar 250 judul puisi. Dialah penyair NTT yang paling produktif.

Setelah menelusuri sekitar 250 judul puisi JDM, ditemukan bahwa "semua puisinya" mencantumkan kolofon pada bagian akhir puisi. Misalnya puisi "Balada Imam," pada bagian akhir puisi tertulis kolofon: Ledalero, November 1978. Artinya, puisi "Balada Imam" itu ditulis di suatu tempat bernama Ledalero, yakni Sekolah Tinggi Filsafat Katolik Ledalero (STFK Ledalero), Maumere, Flores, pada bulan November 1978. Contoh lain, puisi panjang yang merupakan masterpiece JDM berjudul "Doa-Doa Semesta," pada bagian akhir puisi tertulis kolofon: Biara St. Yosef, Ende, Juli-Agustus 1982. Artinya, puisi itu ditulis di suatu tempat bernama Biara St. Yosef di Ende, pada Juli-Agustus 1982 (proses kreatif penciptaan puisi ini selama dua bulan). Dengan demikian, tahapan proses kreatif penyair John Dami Mukese dengan menelusuri kolofon dapat ditelusuri dan diungkapkan yang menjadi tujuan utama artikel ini.

Berdasarkan hasil kajian terhadap sekitar 250 judul puisi JDM, terungkap bahwa penyair ini mulai menulis puisi pada umur 27 tahun, yakni tahun 1977, pada waktu kuliah di STFK Ledalero (1972-1981). Ada dua puisinya yang ditulis pada tahun $1977 \mathrm{itu}$. Hal itu terlihat dalam kolofon puisinya. Meskipun menulis puisi sejak 1977, namun publikasi karya-karya puisinya baru dilakukan dua tahun kemudian (1979). Puisi pertama JDM yang ditulis tahun 1977 berjudul "Kota" termasuk puisi panjang, terdiri atas 5 bagian, 14 bait, dan 80 baris, ditulis pada awal tahun 1977, dimuat dua tahun kemudian dalam majalah dua mingguan Dian (terbitan Ende, Flores), edisi Nomor 6, Tahun VI, 10 Januari 1979, halaman 6. Di bagian bawah puisi ini tertulis kolofon: Sebuah Percakapan di Sebuah Kota Kecil, Timor, Awal Tahun 1977.

Berikut kutipan puisi pertama penyair JDM itu.

1. Matahari sudah jatuh

Di ujung barat kota ini

Kau lihat lampu warna warni itu?

Tanya kawanku

Lalu maksudmu?

Tanyaku balik

Indah mempesona!

Kawanku coba melukis

Jangan keliru - itu menipu!

Kataku sambil lalu

2. Toko-toko berjejer

Kaca-kaca etalase

Jadi semarak disunglap

Sinar neon merah ungu 
Kasihan kawanku

Ia orang udik

Ia datang siang tadi

Matanya melalap menyapu ruangan

Sssstt

Jangan lupa daratan!

Ejekku halus

Kawanku malu tersipu

Ini kota!

Kataku

Banyak barang tidak asli

Puluhan bengkel

Hasilkan barang tiruan

Yang lain barang permak

Awas jangan tertipu

3. Di ujung jalan ada kerumunan orang

Mereka ribut

Kawanku mengajak ke sana

Stop!

Bantahku

Banyak penipu di kota ini

Jangan terseret arus massa

Banyak orang pandai memanfaatkan keadaan

4. Malam makin larut

Bintang-bintang makin banyak

Bunyi jengkerik jelas terdengar

Di sela-sela gelak remaja keluyuran

Di simpang dan lorong-lorong kota

Wah, kau lihat anak-anak dara itu?

Mereka lewat di bawah sinar manca warna

Dan aduhai!

Kawanku tak tahan pesonanya

Hei, hati-hati!

Bisikku

Ini kota!

Ya, ini kota!

Tambah kawanku

Lalu?

5. Dalam kota ini banyak lorong-lorong gelap

Banyak orang hilang jalan

Dan terantuk

Mereka jatuh

Kena lumpur 


\title{
Dan ternoda
}

Tapi mereka tahu akal

Ada salon kecantikan

Mereka mandi parfum

Bersinar cahaya warna warni

Kita tersilau dan keliru

Ada perawan di kota ini?

Tanya kawanku ingin tahu

Ada, tentu!

Tapi banyak yang tidak lagi

Sahutku tak menentu

Dari mana kau tahu?

Kawanku mendakwa

Dari pemuda-pemuda di kota ini

Mereka tahu dan mereka sendiri ....

\author{
Apa? \\ Desak kawanku \\ Mereka punya firasat \\ Sendiri tentang itu \\ Jawabku menutup percakapan \\ Malam itu
}

(Sebuah Percakapan di Sebuah Kota Kecil, Timor, Awal Tahun 1977).

Puisi kedua yang diciptakan pada tahun 1977 itu berjudul "Salam Hai Pahlawan" (Bagi yang Gugur di Timor Timur). Pada bagian akhir puisi tertulis kolofon: Atambua, Timor, 1977. Puisi ini baru diterbitkan 1983 dalam buku antologi puisi pertamanya berjudul Doa-Doa Semesta (Nusa Indah, Ende, 1983, halaman 89). Baik puisi pertama maupun puisi kedua, diciptakan di Kota Atambua, Timor, sebuah kota perbatasan dengan wilayah Timor Timur, yang kini menjadi Negara Timor Leste.

Pada tahun 1978, JDM menulis dua judul puisi, yakni puisi "Mazmur Cinta," ditulis di Ledalero, Oktober 1978, dan puisi "Balada Imam" ditulis di Ledalero, November 1978. Kedua puisi ini baru diterbitkan lima tahun kemudian, yakni dalam buku puisi Doa-Doa Semesta tahun 1983, halaman 86-87 dan halaman 103-108. Pada tahun 1979, penyair JDM menulis tiga judul puisi, yakni (1) Natal Seorang Petani, ditulis di Ledalero, 12 Oktober 1979, dimuat dalam majalah dua mingguan Dian pada edisi Nomor 4, Tahun VII, 10 Desember 1979, (2) Natal dan Nelayan, ditulis di Ledalero, 15 Oktober 1979, dimuat dalam majalah dua mingguan Dian pada edisi Nomor 5, Tahun VII, 24 Desember 1979, (3) Manusia (Siapakah Sesamaku), ditulis di Ledalero, 1 Desember 1979. Ketiga puisi di atas baru diterbitkan dalam buku DoaDoa Semesta tahun 1983. Tahun 1977, 1978, 1979 adalah tahun-tahun awal proses kreatif John JDM. Selama tiga tahun awal ini dijadikan JDM sebagai tahun untuk mencari dan mematangkan bentuk dan ciri khas pengucapan puisi-puisinya. 
Mulai tahun 1980 proses kreatif penyair JDM meningkat dan menemukan ciri khas dan bentuk pengucapan yang pas. Kreativitas dan produktivitasnya terjadi setelah ditahbiskan menjadi pastor Katolik dan bekerja di Penerbit Nusa Indah Ende dan surat kabar mingguan Dian di Ende pada 1981. Masa subur kreativitas dan produktivitasnya berlangsung terus-menerus selama empat tahun berturut-turut, yakni tahun 1980-1984. Sebagian besar puisi JDM yang diterbitkan dalam lima buku puisinya ditulis dalam kurun waktu empat tahun masa subur kreativitas itu.

Boleh dikatakan, masa klimaks kreativitas dan produktivitas penyair JDM terjadi pada waktu umur 30-34 tahun, yakni tahun 1980-1984. Dari segi kualitas puisi dan ciri khas puisinya yang menyatukan tema/amanat religius dengan masalah sosial kaum terpinggirkan sangat kentara dalam puisi-puisi yang diciptakan pada masa emas kreativitas dan produktivitasnya 1980-1984 itu. Gaya pengucapan, diksi, metafora, tema, dan unsur intrinsik puisi lainnya terasa konsisten dipertahankannya sehingga menjadi ciri khas kepenyairannya, religi-sosial.

Mulai tahun 1985 sampai dengan akhir hayatnya tahun 2017 (selama 32 tahun), puisi-puisi yang diciptakannya semakin berkurang. Dia lebih banyak menulis biografi para misionaris Belanda yang berkarya di Flores dalam beberapa jilid buku. Terjadi anti klimaks dalam proses kreatifnya. Tema-tema yang digarap sejak tahun 1985 terasa ada kecenderungan bergeser ke tema religius sehingga mirip doa ditulis dalam bentuk puisi. Tema sosial kemasyarakatan terasa berkurang. Buku antologi Puisi Anggur (2004) dan Kupanggil Namamu Madonna (2004) yang terbit belakangan menunjukkan kecenderungan tersebut.

Puisi-puisi JDM sebagian besar menunjukkan dua nuansa atau ciri khas yang tak terpisahkan, yakni nuansa religius dan sosial atau religio-sosial. Dari lima buku kumpulan puisi pribadinya, dua buku kumpulan puisi yang pekat bernuansa religiososial, yakni buku Doa-Doa Semesta (1983) dan Puisi-Puisi Jelata (1991). Puisi-puisinya mengungkapkan satu pengalaman mendalam dengan realitas Ilahi, baik yang disebut sebagai Tuhan atau Allah maupun yang disebut dengan sapaan-sapaan lain yang diambilnya dari tradisi religius masyarakat Flores. Namun serentak puisi-puisi penyair ini menunjukkan satu sensitivitas yang sangat mendalam terhadap realitas sosial yang tengah berlangsung. Realitas sosial yang dimaksudkan di sini adalah realitas masyarakat miskin, yang kalah dalam persaingan, dan yang terpinggirkan. Mereka semua dibela penyair dalam doa berbentuk puisi. "Doa adalah jeritan yang melengking di bibir derita" tulis Kleden (2009, hal. 435) dalam ulasannya terhadap puisi-puisi JDM.

Banyak puisi JDM yang disusun sebagai doa dengan tema pergulatan hidup yang dihadapi para petani, pekebun, nelayan atau buruh pelabuhan. Puisi-puisi itu bukan sekadar puisi religius yang mengungkapkan relasi penyair dengan Allahnya tanpa kepedulian terhadap apa yang bergejolak dalam masyarakat lingkungan. Puisipuisinya bukan hanya merupakan kritik telanjang penyair mengenai kondisi sosial yang mengelilinginya. Dalam bentuknya yang tertulis sebagai puisi, doa-doa puisi memiliki daya protes dan ungkapan keluhan. Melalui doa-doa puisi ini, penyair tampil sebagai penyuara dan pembela kaum jelata.

Di sini tampak jelas bahwa penyiar JDM berdiri di tengah masyarakat dan zamannya dan menangkap apa yang menjadi keprihatinan dan kegembiraan manusia. Tentang visi penyair yang seperti ini, Waluyo (dalam Kleden, 2009, hal. 453) menulis: "Di tengah kaum papa yang menderita, berdirilah penyair untuk membelanya. Di tengah penindasan dan ketidakadilan, berdirilah penyair untuk 
membela yang tertindas dengan kata-kata dan seruannya. Di tengah si miskin yang lapar, penyair siap membela mereka dengan kata-kata."

Dengan memperhatikan kiprah para penyair sebagai pejuang kemanusiaan, kecemasan dan ketakutan para penguasa otoriter terhadap mereka serta keterlibatan mereka dalam pergerakan menuju perubahan, seperti yang menjadi nyata di Indonesia dalam gerakan mahasiswa pada tahun 1966 dan tahun 1998, kita lebih sepakat dengan apa yang sering kita dengar bahwa kata-kata kadang lebih tajam daripada pedang dan lebih runcing daripada peluru. Karena itu, penguasa otoriter kadang memusuhi penyair, mengejar, memburu, bahkan menangkap dan menghukumnya. Jika penguasa lupa, penyair mengingatkan. Jika penguasa bersikap kejam, penyair memberi teguran. Jika penguasa melupakan si miskin, penyair menyadarkan mereka akan tugasnya. Puisi adalah kekuatan moral untuk menegakkan kebenaran dan keadilan. Penyair JDM coba mengambil bagian dalam peran profetik tersebut.

Di dalam puisi-puisi JDM, elemen religius dan sosial terangkat secara intens dan serentak. Puisi-puisinya adalah sungguh doa kaum jelata. Puisi panjangnya yang berjudul "Doa-Doa Semesta" yang terdiri atas 20 bait dan 296 baris dimuat dalam majalah sastra Horison pada edisi Nomor 2, Tahun 1983, halaman 86-89, merupakan representasi puisi-puisi JDM yang berciri khas religio-sosial tersebut. Berikut ditampilkan bait pertama, kedua, dan ketiga, dari 20 bait puisi "Doa-Doa Semesta" tersebut.

\section{(1)}

Pagi ini ada selembar tangis

dari atap gubuk ilalang berlobang

Selembar tangis bayi pilunya siul elang

pembawa warta lara dukana

lewat akar-akar gantung beringin bertuah

Pagi ini ada selembar tangis

dari puncak bukit azab nan latah

tertimbun sejak kakek dari nenek

setumpuk duka berusia empat turunan

Tiap pagi hidup memang bersemi

Tapi betapa pilunya Tuhan

ketika tangis bayi pagi ini

Kautautkan pada kehidupan kami yang bocor

Dan atap gubuk ilalang berlobang

makin sangsi mempertanyakan:

"Benarkah bahagia si kaum larat?"

Oh, tangis bayi! Tangis bayi!

Pilunya siul pilu elang mengepak lara

Betapa Kautautkan pada

kehidupan kami yang bocor ini!

(2)

Siul burung-burung malam telah pergi

Bersama detak-detak jantung petani

Digetar pematang sawah 
Sungguh bersih hatinya menggenggam rindu

Sejuta mayang padi mekar pagi ini

Tapi adalah dadanya menggendong pula

Sekepal dendam dari belantara:

Walangsangit musuh abadi

Hari ini juga mulai beraksi

Bapa, mestikah rindu petani digalau risau

Pada menatap mayang-mayang kehidupannya?

Wahai rindu petani!

Duhai dendam peladang!

Marilah berdoa mohon damai!

(3)

Sahabat,

Di pulau ini pisang adalah sisa-sisa

Kelembutan hati-Mu setia abadi

Rabalah jantungnya berdenyut

Pada tandan runduk terjuntai

Tidakkah itu sisa-sisa cinta-Mu jua?

Jangan biarkan ia punah, Sahabat!

Pulau kami memang gersang

Tapi ia masih sanggup

Membuahkan kelembutan hati-Mu

Puisi "Doa-Doa Semesta" di atas, adalah sebuah doa kemanusiaan. Penyair JDM menempatkan dirinya sebagai individu mewakili keresahan masyarakat kecil. Seorang JDM sedang menderaskan doa semesta. Tentang kisah pilu kaum larat. Kadang ia juga mengeluh, mengapa kisah-kisah pilu sering ditimpakan ke atas kaum yang melarat. Terdapat narasi berulang, yang jika dibaca secara cermat merupakan protes kepada Tuhan atas apa yang terus-menerus dan selalu saja terjadi. Pada baris / Pagi ini ada selembar tangis/ diulang dua kali. Sedangkan, pada baris / Tiap pagi hidup memang bersemi/ adalah variasi penggunaan diksi yang menunjukkan kreativitas pengarang dengan tujuan tidak membosankan. Frase pagi ini yang diulang sebanyak dua kali, dan perulangan yang ketiga pengarang memilih diksi tiap pagi. Sebenarnya inilah pertanyaan mendasar penyair, akan hanya sebeginikah nasib kaum larat, Tuhan?

Dalam cara pandang yang berbeda, penyair JDM ingin mengajak kaum larat (masyarakat kecil dan miskin) untuk membangun solidaritas kemanusiaan bersama dalam merawat rumah kehidupan kemanusiaan. Eksplorasi kemanusiaan demi merawat nilai-nilai kemanusiaan universal. Jika upaya merawat nilai-nilai universal tersebut tidak dilakukan secara serius, maka hidup hari ini, esok, dan barangkali yang akan datang, akan tetap bocor.

Dengan demikian, JDM menjadi seorang penyair yang tanpa henti terlibat dalam persoalan kemanusiaan, terutama tentang melestarikan prinsip-prinsip dan menjunjung tinggi nilai-nilai kemanusiaan. Itu dilakukannya sebagai bentuk tanggung jawab dan keberpihakannya terhadap kaum larat yang terwakilkan pada diri petani dan peladang. Dalam konteks ini, JDM disebut sebagai "kreator" atau pelaku yang sadar bertindak mengatasi gejala atau realitas "kelupaan" akan sesuatu 
di masa lampau. Bagi peneliti, ia adalah individu yang keberjagaan hatinya selalu disemangati oleh elan-kolektif, suatu situasi hari ini, masa lampau, dan yang akan datang. Oleh karena itu, bagi JDM kisah atau sesuatu yang terjadi pada masa lampau adalah medan, lapangan, atau ruang yang strategis untuk berkreasi atau mencipta. Ruang-ruang masa lampau dan yang akan datang menjadi lokus pertemuan dan perjumpaan sekaligus percampuran banyak hal: antara budaya tradisional vs modern, kawan vs lawan, salah vs benar, hitam vs putih, termasuk budaya akibat perubahan (hibriditas budaya), meminjam konsep Homi Bhaba (dalam Sayuti, 2014, hal. 12).

Elemen religius dan sosial dalam puisi-puisi JDM terangkat secara intens dan serentak. Puisi-puisinya adalah sungguh doa kaum jelata. Membaca doa-doa puitis seorang penyair, orang dapat saja mengatakan bahwa penyairnya tidak mesti seorang pendoa untuk dapat menghasilkan puisi-puisi doa. Seperti halnya dengan penyair Rendra yang menulis puisi "Doa Seorang Serdadu Sebelum Berperang," tanpa mesti menjadi serdadu. Eka Budianta menulis surat dari seekor kupu-kupu dalam puisinya "Jendral dan Kupu-Kupu," tanpa harus menjadi kupu-kupu. Demikian halnya dengan penyair JDM, menulis "Puisi-Puisi Jelata" tanpa harus membuat penyairnya menjadi seorang jelata. Seseorang dapat saja menulis puisi doa tanpa harus menjadi seorang pendoa.

Saat menulis "Doa Seorang Serdadu Sebelum Berperang", Rendra sama sekali tidak mengenal dunia para serdadu, kegelisahan yang mereka hadapi, kecemasan dan ketidakpastian yang menggerogoti hati dan pikiran mereka. Eka Budianta ketika menulis puisi "Jendral dan Kupu-Kupu" seandainya dia tidak memperhatikan secara saksama apa yang dilakukan seseorang jendral dan bagaimana sikap kupu-kupu, apabila dia tidak memiliki kemampuan berempati dengan kupu-kupu. Demikian pula halnya dengan penyair JDM. Sulit dibayangkan penyair JDM dapat merangkai kata, mengungkapkan duka, dan harapan kaum jelata, apabila dia sama sekali tidak mengenal dunia mereka, seandainya dia tidak berbela rasa dengan kaum tertindas: petani, peladang, nelayan, dan kaum buruh. Puisi-puisi doanya pun tidak mungkin lahir kalau penyairnya tidak mempunyai relasi yang harmonis dengan Allah Maha Pengasih dan Penyayang.

Tentang relasi penyair dengan Allah seperti ini, Kleden (2009, hal. 465-466) menyatakan bahwa relasi dengan Allah itulah yang merupakan latar belakang munculnya doa-doa yang bernuansa puitis. Kisah cinta bermula dari getaran jiwa. Cinta adalah getaran, yang kadang sangat halus sehingga orang dapat menyembunyikannya. Demikian pula puisi dan doa adalah getaran. Keduanya sanggup merangkum alam semesta. Keduanya dapat lahir dari orang-orang yang membiarkan dirinya digetarkan oleh kisah cinta. Cinta yang dimaksud, yang merangkum alam semesta, adalah cinta yang peduli, cinta yang berpihak. Cinta itu memalingkan wajahnya pada mereka yang berduka, digetarkan oleh pengalaman mereka yang tersisih. Puisi-puisi JDM lahir dari kepekaannya akan dunia dan pengalaman kaum jelata.

\section{PENUTUP}

Berdasarkan hasil penelusuran terhadap riwayat hidup dan riwayat penciptaan puisi-puisi penyair JDM sebagaimana digambarkan di atas, JDM mulai menulis puisi pada umur 27 tahun, yakni tahun 1977, pada waktu kuliah di STFK Ledalero. 
Ada dua puisinya yang ditulis pada tahun 1977 itu. Pada tahun 1978 dia menulis dua puisi, dan pada 1979 menulis tiga puisi. Hal itu dapat ditelusuri karena pada bagian akhir setiap puisinya tercantum kolofon, nama tempat dan tanggal kelahiran puisi. Meski menulis puisi sejak 1977, namun puisi-puisinya baru dipublikasi pada tahun 1979, dua tahun kemudian.

Masa klimaks kreativitas dan produktivitas penyair JDM terjadi pada umur 3034 tahun, yakni tahun 1980-1984. Umur 30-an adalah umur kreativitas dan produktivitas seorang JDM. Puisi-puisinya menyatukan tema dan amanat religius dengan masalah sosial masyarakat terpinggirkan, sangat kentara dalam puisi yang diciptakan pada masa emas kreativitas dan produktivitas tersebut. Gaya pengucapan, diksi, metafora, tema, dan unsur intrinsik puisi lainnya terasa konsisten dipertahankannya sehingga menjadi ciri khas kepenyairannya. Mulai tahun 1985 sampai dengan akhir hayatnya 2017, puisi-puisi yang diciptakannya tidak saja berkurang dari segi jumlahnya, tetapi merosot dari tema khas puisinya. Terjadi anti klimaks dalam proses kreatifnya.

Puisi-puisi JDM sebagian besar menunjukkan dua nuansa atau ciri yang tak terpisahkan, yakni nuansa religius dan sosial, atau religi-sosial. Puisi-puisinya mengungkapkan satu pengalaman yang mendalam tentang realitas Ilahi, baik yang disebut sebagai Tuhan atau Allah maupun yang disebut dengan sapaan-sapaan lain yang diambilnya dari tradisi religius masyarakat Flores. Namun serentak, puisi-puisi penyair ini menunjukkan satu sensitivitas yang sangat mendalam terhadap realitas sosial yang tengah berlangsung. Realitas sosial yang dimaksudkan adalah realitas masyarakat miskin, yang kalah dalam persaingan, dan terpinggirkan. Mereka semua dibela penyair dalam doa berbentuk puisi, puisi berbentuk doa.

\section{DAFTAR PUSTAKA}

Abrams, M. H. (1971). The Miror and the Lamp: Romantic Theory and the Critical Tradition. Oxford: Oxford University Press.

Anggaira, S. A., \& Emawati. (2018). Tentang Sastra: Orkestrasi Teori dan Pembelajarannya. Yogyakarta: Garudhawaca.

Damono, S. D. (Ed.). (2018). Jejak Pengarang dalam Sastra Indonesia (1880-1980). Jakarta: LIPI Press.

Kantor Bahasa NTT. (2013). Senja di Kota Kupang: Antologi Puisi Sastrawan NTT. Kupang: Kantor Bahasa NTT.

Kleden, P. B. (2009). Doa adalah Jeritan yang Melengking di Bibir Derita: Menyelisik Makna Doa Sosial dalam Puisi-Puisi John Dami Mukese. In P. B. Kleden \& O. G. Madung (Eds), Menukik Lebih Dalam: Kenangan 40 Tahun STFK Ledalero. Maumere: Ledalero.

Mahayana, M. S. (Ed.). (2017). Apa \& Siapa Penyair Indonesia. Jakarta: Yayasan Puisi Indonesia.

Mu'jizah. (2018). Menelusuri Proses Kreatif Muhammad Bakir. In S. D. Damono (Ed.), Jejak Pengarang dalam Sastra Indonesia (1880-1980). Jakarta: LIPI Press.

Mukese, J. D. (1991). Puisi-Puisi Jelata. Ende: Nusa Indah.

Mukese, J. D. (2004). Kupanggil Namamu Madona. Jakarta: Obor.

Mukese, J. D. (2015). Doa-Doa Semesta. Cetakan ke-3. Ende: Nusa Indah. 
Sayuti. S. A. (2014). Bahasa (Ibu) dan Upaya Dinamisasi Budaya. Bandung: Unpad Press.

Sehandi, Y. (2012). Mengenal Sastra dan Sastrawan NTT. Yogyakarta: Universitas Sanata Dharma.

Sehandi, Y. (Sep 2018). Penyair John Dami Mukese di Panggung Sastra. Flores Pos.

Suryadi AG, L. (Ed.). (1987). Tonggak 4: Antologi Puisi Indonesia Modern. Jakarta: Gramedia.

Taum, Y. Y. (Ed.). (2014). Ratapan Laut Sawu: Antologi Puisi Penyair NTT. Yogyakarta: Universitas Sanata Dharma.

Wellek, R., \& Waren, A. (1962). Theory of Literature. New York: A. Harvest Book Harcourt, Brace \& World, Inc. 
